\title{
Sengkulun as Betawi Traditional Cake Philosophy, Historical and Cultural Review
}

\author{
Billy Tanius $^{1}$, Tiurma Sinaga ${ }^{2}$ and Himawan Brahmantyo ${ }^{3}$ \\ ${ }^{1}$ Podomoro University Jakarta \\ ${ }^{2}$ Department of Community Nutrition, Faculty of Human Ecology, IPB Darmaga Bogor \\ ${ }^{3}$ Sekolah Tinggi Pariwisata Trisakti Jakarta
}

Corresponding author: Billy.tanius@ podomorouniversity.ac.id

\begin{abstract}
ARTICLE INFO
Received

25 January 2018

Accepted

12 March 2018

Available online

30 March 2018

ABSTRACT

Betawi has a diversity of traditional food. One of the diversity of traditional foods of Betawi's type of cake is Sengkulun cake. This rare cake is made from glutinous rice flour. Study was designed to recognize the Sengkulun cake from history, culture and philosophy as well as documenting the original way of making the cake which has begun to be forgotten. Descriptive qualitative approach was used to analyse data and information. Respondent were elders, i.e. Betawi cultural experts and Sengkulun cake makers. Experiment was conducted to obtain documentation in the form of photo and video which could make the cake more interesting to become Betawi 's snacks. Results show that the Sengkulun cake has existed for a long time but cannot be known with certainty the year of the creation of this cake. This cake began to be created because of the abundant availability of glutinous rice and also due to the influence of Chinese ethnic in the processing the snacks. The cake has a high position in ancient times because this cake can only be found in certain events such as Eid al-Fitr. From the Sengkulun's philosophy, it can be said that sticky texture of the Sengkulun cake has a symbol of respect each other.
\end{abstract}

Keywords: philosophy, Sengkulun, traditional cake

\section{Introduction}

\section{Background}

Jakarta is a city that has many functions and roles. Jakarta as the capital of the province and also the state capital. the hustle of routine as the center of government, the trading city, the administrative center, the central political activity, and the educational center, as if ceaselessly offering modernity, which almost eliminates the identity of Jakarta. Jakarta is unique because it cannot http://ojs.unud.ac.id/index.php/eot simply represent the ethnic population of the original, namely Betawi, but also home to various humans, tribes, cultures, and other ethnic who come, live, and thrive in it. The epistemology of Jakarta culture is a mixed culture or culture of various ethnicities. Since the Dutch era, Jakarta is the capital of Indonesia which attracts migrants from within and outside the archipelago. The tribes inhabiting Jakarta, among others, Java, Sunda, Minang, Batak, and Bugis (Martiah, 2013). Apart from the population of the archipelago, 
Jakarta culture is also absorbed from many foreign cultures, such as Arabic, Chinese, Indian and Portuguese. With cultural diversity that ultimately mutually acculturates affect traditional culinary products contained in Jakarta. Cultural assimilation was inevitable, especially since the first city of Jakarta has become a melting pot. Various local and foreign ethnic crowded the city of Jakarta. Status as a modern city with a massive wave of development invasion also played a role to wipe out the existence of ethnic Betawi, the original inhabitants of Jakarta who deserved the presence of the newcomers (Lila, 2016).

Before the 1960s in the center of Jakarta there were many Betawi settlements, but due to the development and industrialization, many Betawi Kota people moved to the outskirts of Jakarta (Shabab, 2004). Land owned by Betawi people more and more are traded freely. The city of Jakarta was later abandoned the original inhabitants, changed with the immigrants who race to taste the beautiful metropolitan. Under the guise of globalization, traditional Betawi wisdom is increasingly felt strange in his own village. In addition to its predicate as a metropolitan city, other tourist attraction is said to have come from a number of art and cultural festivals held in Jakarta (Deny, 2014). Therefore, in addition to offering the splendor of a sparkling urban city with luxurious facilities, Jakarta should also more often showcase the uniqueness of Betawi ethnic culture, including culinary, which is loaded with historical value and philosophy.

As one of the tourist destinations in Indonesia, quite a lot of Jakarta's local culture can be developed and promoted, including culinary riches. There are a line of delicious and unique dishes that are very potent Betawi so the appeal of the culinary tourist, either because of taste, health benefits, or the value of philosophy and history that accompany it. Unfortunately until now the Betawi culinary wealth has not become a reason for tourists to come to Jakarta. Betawi culinary tour in Jakarta is still not well known, still far behind the popularity of shopping center and family recreation center. In the official website of Jakarta Tourism and Culture Department, the

http://ojs.unud.ac.id/index.php/eot choice of Betawi restaurant or restaurant is not in the recommended Indonesian food reference (Lila, 2016).

Betawi typical food as its culture is a blend of elements from outside such as culinary from China, Middle East and the Netherlands. The cuisine of these elements can be recognized in the typical Betawi cuisine, but there are some dishes that are purely derived from outside but in the spread of the food undergoes a name change. Betawi has a diversity of artistry such as music, dance, tourist attractions, and food. The diversity is also influenced by other cultures, one of which is seen from the diversity of traditional Betawi food of cake that is influenced from the Chinese cultural traditions that are visible from various types of food typical of Betawi (Dwi, 2015).

One of the Betawi culinary that is influenced by Chinese culture is Sengkulun . But this cake is now beginning to be difficult to obtain, even practically rare. Sengkulun is a cursory look like a basket. Cake that is made from glutinous rice, has a rough nodded surface, texture is soft and chewy. Originally Sengkulun made from Java brown sugar. This traditional food began to be difficult to obtain, practically rare in fact. The causes are varied; no one can make it anymore, less favored and no popularization and no future generations. Too bad if traditional food goes extinct one by one.

Based on the background of the above problems to be able to preserve traditional Betawi food, especially Betawi cake which is increasingly difficult to obtain, while this cake is a cultural heritage that needs to be maintained, especially in the effort to preserve the culinary of the archipelago as a part of national tourism development, proposed a research topic on Betawi Culinary Cake as Betawi traditional culinary.

\section{Reseach Objectives}

This study only reviewed the Sengkulun cake in terms of Philosophy, History and Culture, looks at how the original way of making Sengkulun cakes to be able to be documented and develops Sengkulun product to be more acceptable by society. the 
purpose of the research is to know the history, philosophy and culture of Betawi Sengkulun cake and to preserve the Betawi Sengkulun cake. Research Benefits are providing information in the form of valid documents as a Betawi traditional culinary reference, Introducing Sengkulun cake as traditional Betawi snack and preserving Sengkulun cake to be known by the community.

\section{Literature Review}

\section{History}

History is chronological study that interpret and gives meaning to events and applies systematic methods to discover the truth. History is continuous process of interaction between the historian and his fact, unending dialogue between the present and the past (Carl, 1985). Every historian would agree, I think that history is kind of research or inquiry.

\section{Philosophy}

Philosophy is an attitude toward life and universe; philosophy is a method of reflective thinking and reasoned inquiry; philosophy is a group of problem; philosophy is a group of system thought (Harold, 2015).

\section{Culture}

According to structuralism, contains the basic idea as follows. Structuralism views that all societies and cultures have the same and fixed structure. This belief believes that every human being possesses a genetically inherited basic ability that this ability exists in every normal human being. This understanding places the structure of Language and culture as forces and even human consciousness. In this case, ceremonies, systems, kinship, marriage, cooking dress are the pattern of Language. Cultures such as Languages in which there are hidden rules governing the behavior of society. This hidden rule is what makes a community group unique and different from other community groups.

\section{History of Betawi}

Betawi tribe is a tribe in Indonesia whose inhabitants generally reside in Jakarta. Some argue that the Betawi tribe is derived from inter-ethnic and inter-mawin marriages in the past. Biologically, those who claim to be Betawi people are descendants of bloody mix of various tribes and nations imported by the Dutch to Batavia. The so-called Betawi people or tribes actually counted newcomers in Jakarta. This ethnic group was born from a combination of various other ethnic groups who already live in Jakarta, such as Sundanese, Javanese, Arabic, Balinese, Bugis, Makassar, Ambon, Malay and Chinese (Murni, 2012).

\section{Cooking Method}

Traditional food cooked with certain cooking methods or techniques to produce different textures and food products. Some cooking techniques with water convection is steaming, The cooking process is moist or wet, with heat from steam or with steamed terms. In this Sengkulun cake research is cooked in a way steamed.

\section{The Cake Sengkulun}

According to Indra Ketaren in Upa Boga Indonesia, typical food from Betawi which is cursory like a basket cake but the surface is rough. A sweet savory sweet flavor with a supple and soft texture. Sengkulun is made with the main raw material of sticky rice flour. The color of chocolate Because it uses brown sugar as well as a sweetener in addition to using sugar as well. While that makes it tasty, no other thick coconut milk. Steam time long enough, about 2 hours.

This food is not really pure Betawi, but there is the influence of Chinese culture. Admittedly, Chinese culture is strong enough to penetrate the Betawi culture. On Idul Fitri and Idul Adha, usually Kue Sengkulun is often served. Cake with basic ingredients sago and glutinous flour is very tasty in combination with grated coconut. The area of this cake distribution is cultivated in certain areas on the border area of east and south Jakarta (Murni, 2012; Felicia, 2014). 


\section{Methodology}

\section{Design and Time}

Methods are a way of expressing objective truth. This method is intended to reveal that the expressed truth is based on sound scientific evidence. Therefore, methods can also be interpreted as procedures or sequences of ways that systematically extract scientific truths (Firta, 2015). This research uses descriptive method with qualitative approach. Qualitative approach is a research process that produces descriptive data in the form of oral words of people and behavior observed (Bogdan and Taylor, 1992). Qualitative approach was chosen in this study to see the essence of research so that the results obtained detailed. Qualitative research has the following characteristics.

a. There is a natural research background and researchers act as this instrument. Researchers are mostly at the research site to observe and understand the problem in depth. Researchers also use a tape recorder to document data in words and cameras to document in the form of images.

b. Descriptive nature, the researchers will describe the problem of research with the detailed data collection and complete.

c. More emphasis on process than product. The process is more emphasized because research begins with "how" and not "what".

d. Tend to analyze data inductively. The research begins with a way of looking at the specific circumstances in society and then drawn general conclusions based on the development of ideas from existing theories.

e. In qualitative research, which is very important. This approach emphasizes the importance of fast and accurate capture of post-insights.

This type of research uses a descriptive approach, i.e., a study that aims to provide or describe a state or phenomenon that occurs today by using scientific procedures to answer the problem in actual (Sugiyono, 2010). Descriptive research tries to find the right and sufficient description of all activities, objects, processes and people (Basuki and Sulistyo, 2010). The method used in the study was descriptive and qualitative by in-depth interview with snowball technique and observation. Observations carried out to see how to make Sengkulun cake. The study was conducted from April to August 2017 in Jakarta especially at central Jakarta.

\section{a. Research Informants}

Informants of the research are selected speaker namely Indigenous Elders Betawi, Cultural Betawi and Sengkulun cake maker.

\section{b. Research Instrument}

Research tool used in collecting data in the form of interview guide in form of questions, observation record and documentation.

\section{Sources of data}

Data was collected using snowball sampling technique. According Sugiyono (2010:85) "snowball sampling is a technique of determining samples at first small amount then become big". If the data collection of the first respondent has been completed, the researcher requests that the respondent provide a second and further recommendation. This process lasts until the researchers obtain sufficient data and as needed.

\section{Data collection technique}

Data collection is a very important step in the research, a researcher must be skilled in collecting data in order to obtain valid data. Data collection is a systematic and standard procedure for obtaining necessary data. In qualitative research the techniques used are observation (observation), in-depth interview, and documentation.

\section{a. Observation}

In Qualitative Research, the observation is clarified into 3 ways: observers can act as participants or nonparticipants, observation can be done frankly or disguise, and observation concerning the research background (Sugiyono, 2010) and in this research used observation technique which where researcher act as participants Observations conducted by the author in this study is the observation frankly, in this 
case the authors do data collection that researchers are doing research on Sengkulun cake.

\section{b. Depth Interview}

In the technique of gathering using interviews is almost the same as the questionnaire. The interview itself was divided into 3 groups: structured interviews, semi-structured interviews, and in-depth interviews. Researchers chose to conduct in-depth interviews, aiming to collect complex information, most of which contain opinions, attitudes, and personal experiences (Basuki and Sulistyo, 2010). To avoid losing information, the researcher asks the resource person to use the tape recorder. Before an in-depth interview, the researcher explains or gives a brief and clear overview of the topic of research.

\section{c. Documentation}

The document according to Sugiyono (2010: 240) is a record of events that have passed. Documents used by researchers here in the form of photographs, images, and data about the Sengkulun cake. The results of the observations and interviews will be more legitimate and reliable if supported by photographs.

\section{Data Analysis}

Descriptive qualitative was used to analyze the data and information which were collected based on in-depth interview and playing back the recorded interview

\section{Results and Discussion}

\section{Characteristics of Respondents}

There were 8 respondents in this research. Most of their age were 40 years to 80 years. All of them live in Jakarta. They have direct experience of undergoing Betawi traditional food. All of interviewees know about Sengkulun cake. Four respondents are as Sengkulun cake maker and other respondents are organizers of Betawi cultural institutions at Jakarta.
Table 1. Profile of Respondents

\begin{tabular}{ccl}
\hline Respondent & Age & \multicolumn{1}{c}{ Accupation } \\
\hline 1 & 56 & LKB Development \\
\hline 2 & 47 & LKB Development \\
\hline 3 & 63 & Setu Babakan \\
\hline 4 & 89 & Sengkulun maker \\
\hline 5 & 59 & Teacher at LKB \\
\hline 6 & 72 & Sengkulun maker \\
\hline 7 & 59 & Sengkulun maker \\
\hline 8 & 62 & Sengkulun maker \\
\hline
\end{tabular}

\section{History about Sengkulun}

The results show that Sengkulun has been known since long time ago, even since their's Grandpa and grandmother was born this Sengkulun already exist. But it is not known exactly when the cake began to be made. The Table 2 shows the answer about how long has Sengkulun cake been known?

Table 2. Sengkulung Cake has been known by Betawi people

\begin{tabular}{cl}
\hline Informan & \multicolumn{1}{c}{ Answer } \\
\hline 1 & $\begin{array}{l}\text { As Abang, I know this cake since I } \\
\text { was child }\end{array}$ \\
\hline 2 & $\begin{array}{l}\text { Clearly since I was child this cake } \\
\text { already exist. }\end{array}$ \\
\hline 3 & $\begin{array}{l}\text { Since I was childhood my parents } \\
\text { have introduced this cake }\end{array}$ \\
\hline 4 & I know this from my grandmother \\
\hline 5 & $\begin{array}{l}\text { I have known Sengkulun from my } \\
\text { grandmother and my grandfather }\end{array}$ \\
\hline 6 & $\begin{array}{l}\text { Since my Grandmother tough me } \\
\text { how to made this cake }\end{array}$ \\
\hline 8 & $\begin{array}{l}\text { Since I childhood my Grandfather } \\
\text { show me how to made Sengkulun. }\end{array}$ \\
\hline I know Sengkulun since I was \\
childhood.
\end{tabular}

The origin of Sengkulun is estimated to begin to be made from the availability or harvest of glutinous rice is abundant. The influence of immigrants from ethnic Malays and Chinese such as making basket cake, the Betawi residents allegedly adopted the way of making Sengkulun by using glutinous rice that is easily obtained at that time. At least references related to Betawi traditional cake caused the history of Sengkulun become limited. From the results of extracting 
information from the sources, only a small number of informants who have the belief and the opinion that Sengkulun is a Betawi traditional cake made without any influence from other cultures. But most of the informants argue that because Betawi past is a gathering place of various ethnicities and nations, it is suspected of strong ethnic Chinese influence that inspires the making of this Sengkulun. The Table 3 shows how the origin of the Sengkulun cake is created?

Table 3. The Originality of Sengkulun Cake

\begin{tabular}{cl}
\hline Informan & \multicolumn{1}{c}{ Answer } \\
\hline 1 & $\begin{array}{l}\text { Over production so our eldery use } \\
\text { ingredient to make Sengkulun }\end{array}$ \\
\hline 2 & $\begin{array}{l}\text { Production of glutinous rice need lot of } \\
\text { time and got the influence of the } \\
\text { Chinese culture about making this cake. }\end{array}$ \\
\hline 3 & $\begin{array}{l}\text { Betawi has the cake since long time ago } \\
\text { as we have a lot of glutinous rice }\end{array}$ \\
\hline 4 & $\begin{array}{l}\text { Richness of agriculture in the form of } \\
\text { glutinous rice, Farmers make the cake } \\
\text { following the Chinese people. }\end{array}$ \\
\hline 5 & $\begin{array}{l}\text { Sengkulun cake is real cake from } \\
\text { Betawi culture }\end{array}$ \\
\hline 6 & $\begin{array}{l}\text { Chinese culture influence the existence } \\
\text { of Sengkulun cake }\end{array}$ \\
\hline 7 & $\begin{array}{l}\text { Chinese culture influence us how to } \\
\text { make the cake }\end{array}$ \\
\hline 8 & $\begin{array}{l}\text { Abundant of glutinous rice production } \\
\text { make grandparents created the cake } \\
\text { adopted from Chinese people }\end{array}$ \\
\hline
\end{tabular}

From the interview it is clear that the existence of this cake has been rare and less well known by the Betawi people, especially young people. But this cake has long been known as a snack and is an offering cake for the elderly or magnifying people in the past. This cake has a position that is considered high in the past, because only made and intended to people who are respected or have a high position in the community. It is also reinforced by the making of cakes that are only performed at large ceremonies on the feast of Eid al-Fitr and Eid al-Adha. Table 4 shows how is the position of Sengkulun in today's Betawi society?
Table 4. The Position of Sengkulun Cake in Today's Betawi Society

\begin{tabular}{cl}
\hline Informan & \multicolumn{1}{c}{ Answer } \\
\hline 1 & $\begin{array}{l}\text { Sengkulun known as cake for } \\
\text { offering for the eldery for now } \\
\text { days young people will not } \\
\text { known about this cake. }\end{array}$ \\
\hline 2 & $\begin{array}{l}\text { Rare cake for young people } \\
\text { serve for the one who are } \\
\text { respected }\end{array}$ \\
\hline 3 & $\begin{array}{l}\text { Sengkulun usually for eldery } \\
\text { and served at eid al fitri and eid } \\
\text { al fitr. }\end{array}$ \\
\hline 4 & $\begin{array}{l}\text { for young betawi will not know } \\
\text { Sengkulun, because theres no } \\
\text { one sold this cake and usually } \\
\text { this cake on eid al fitr }\end{array}$ \\
\hline 6 & $\begin{array}{l}\text { Cake for respected the eldery } \\
\text { Already known sengkulun, } \\
\text { never sold in the market as well }\end{array}$ \\
\hline 7 & $\begin{array}{l}\text { Rare cake for respect the eldery } \\
\text { usually at eid al fitr an edi adha. }\end{array}$ \\
\hline 8 & $\begin{array}{l}\text { Young people don't know about } \\
\text { history of Sengkulun cake }\end{array}$ \\
\hline
\end{tabular}

Results of interviews show that all sources said that the cake is widely known by Betawi people, especially Betawi Central Jakarta and surrounding areas. The existence of the mapping of Betawi food is known that the distribution of this cake is only found in Betawi people living around Central Jakarta. Sengkulun in Betawi society is better known by Betawi people in central areas such as Central Jakarta and surrounding areas, such as Kebun sirih area and Kebun Kacang. The results of interviews with some Betawi culinary experts and also the makers of Sengkulun is a cake or snack that is only held for certain events so that it becomes a proud thing for the Betawi people or families who can prepare it outside the special event. It can be concluded that the Betawi people who live in Central Jakarta and surrounding areas are still quite know and play a role in introducing this Sengkulun. The Table 5 shows the role of community groups in the existence of Sengkulun cake. 
Table 5. Role of Community Groups in the existency of Sengkulun cake

\begin{tabular}{cl}
\hline Informan & \multicolumn{1}{c}{ Answer } \\
\hline 1 & $\begin{array}{l}\text { This cake is only in the central area } \\
\text { of Betawi }\end{array}$ \\
\hline 2 & $\begin{array}{l}\text { All Betawi should know this, but } \\
\text { the most area is in the central area }\end{array}$ \\
\hline 3 & $\begin{array}{l}\text { Central Jakarta know more about } \\
\text { Sengkulun cake }\end{array}$ \\
\hline 4 & $\begin{array}{l}\text { Since I was a child, Sengkulun } \\
\text { already exist at my area Kebun } \\
\text { sirih }\end{array}$ \\
\hline 5 & $\begin{array}{l}\text { I live at Kemayoran, and } \\
\text { Sengkulun still exist there. }\end{array}$ \\
\hline 6 & \begin{tabular}{l} 
At the central area \\
\hline 7
\end{tabular} \\
\hline $\begin{array}{l}\text { Betawi people at my place } \\
\text { cake. But central Jakarta at my } \\
\text { place Kebun Kacang still have } \\
\text { received order for this cake. }\end{array}$ \\
\hline
\end{tabular}

\section{Philosophy of Sengkulun}

Sengkulun made from glutinous rice flour has a special characteristic where the cake is more sticky if not eaten with grated coconut. From the results of interviews with informants who know about the existence of Sengkulun. This cake becomes a symbol to stick each other together. This cake is often found in the wedding ceremony, which is expected to be a mutual attachment between husband and wife. This cake is a tradition for Eid al Fitr and Eid al Adha where the existence of this cake to glue the relationship with one another in the family, At the time of Eid Fitr and Eid al-Adha where the relatives gathered with the existence of this sengkulun can be meant glue outgoing relationships with each other. The Table 6 shows the philosophy of Sengkulun cake in Betawi.

Table 6. Philosophy of Sengkulun Cake in Betawi

\begin{tabular}{cl}
\hline Informan & \multicolumn{1}{c}{ Answer } \\
\hline 1 & Especially for Lebaran, \\
& incidentally for certain people is \\
& also used as a dish of Eid adha \\
& and Idul fitri, so it's more like \\
& Lebaran because the meaning of \\
\hline
\end{tabular}

\begin{tabular}{cl}
\hline the sticky cake will attach family \\
relationships
\end{tabular}

The cake is a tradition for Eid and Eid al-Adha (Murni, 2012) where the existence of this cake to glue the relationship with one another in the family, At the time of Idul Fitri and Idul Adha where the relatives gathered with the existence of this sengkulun cake it can be intended to glue relationships with one another. Ketan itself in the belief of Javanese society has many meanings. Ketan can be interpreted "kraketan" or "ngraketke ikatan ", which means to bond the bond. As a symbol of glue rope brotherhood among human beings. It is also marked by the distribution of the dish to the neighbors and relatives to keep the intimacy closer. from this glutinous meaning, Sengkulun based on glutinous rice flour can have meaning, the presentation is used to glue the relationship of both husband and wife and relative relationship.

\section{Culture of Sengkulun}

The results show that from interviews point of view, the cake is mentioned that most likely "Sengkulun" because of the characteristic of the dough is first laid to add to the paste that has been steamed half cooked. But some Betawi culinary experts say because this cake is devoted to the elderly in ancient times is referred to as "Penghulun" this term that makes this cake named Sengkulun. The Table 6 shows any meaning of Sengkulun cake. 
Table 7. Any Meaning of Sengkulun Cake

\begin{tabular}{cl}
\hline Informan & \multicolumn{1}{c}{ Answer } \\
\hline 1 & $\begin{array}{l}\text { because this cake for eldery, eldery } \\
\text { is reffered as penghulun. So we call } \\
\text { the cake Sengkulun. }\end{array}$ \\
\hline 2 & $\begin{array}{l}\text { story from the community who } \\
\text { consider the elderly as Penghulun. }\end{array}$ \\
\hline 3 & $\begin{array}{l}\text { sengkulun means chewy and sticky } \\
\text { and this cake for penghulun ( } \\
\text { eldery) }\end{array}$ \\
\hline 4 & $\begin{array}{l}\text { because pulun ( method of making } \\
\text { this cake ) we can call this cake } \\
\text { Sengkulun }\end{array}$ \\
\hline 5 & $\begin{array}{l}\text { because how to make cake surface } \\
\text { by pulun-pulun , we name it } \\
\text { Sengkulun }\end{array}$ \\
\hline 6 & $\begin{array}{l}\text { since childhood already Sengkulun } \\
\text { because that small round shape on } \\
\text { the cake we call pulun }\end{array}$ \\
\hline 8 & $\begin{array}{l}\text { because printil on the top of cake, } \\
\text { that pulun as sengkulun. }\end{array}$ \\
\hline
\end{tabular}

Most of the sources said this cake can be served as a daily dish. However, according maker of Sengkulun, this cake is only made for certain events in Betawi culture, but can be enjoyed daily if bespoke to the maker to be enjoyed at special family event outside of big days or famous Betawi traditional ceremonies. The Table 8 shows result of the Sangkulun cake which has become a daily cake dish.

Table 8. Sangkulun Cake has become a Daily Cake Dish

\begin{tabular}{|c|c|}
\hline Informan & Answer \\
\hline 1 & $\begin{array}{l}\text { Only for certain event dishes, but can } \\
\text { be ordered if you want to enjoy }\end{array}$ \\
\hline 2 & $\begin{array}{l}\text { I think this cake you can enjoy it any } \\
\text { time }\end{array}$ \\
\hline 3 & $\begin{array}{l}\text { In the past this cake has been sold } \\
\text { but now people try to make their } \\
\text { own cake }\end{array}$ \\
\hline 4 & We can use daily \\
\hline 5 & $\begin{array}{l}\text { Can create for daily but can be order } \\
\text { for engagement }\end{array}$ \\
\hline 6 & Food can be made anytime \\
\hline 7 & $\begin{array}{l}\text { Only for certain event but we can } \\
\text { order to sengkulun maker if we want } \\
\text { to enjoy it. }\end{array}$ \\
\hline 8 & Any time you can enjoy this cake \\
\hline
\end{tabular}

The way of making that is by pulunpulun which a mixture of glutinous rice flour and rice flour mixed with palm sugar mixture until the form of grain is a special technique in making this cake. Almost all of informant said about making pulun is one of special technique in making of Sengkulun. Results Interviews the main ingredients of sengkulun are Glutinous rice flour, rice flour, Java sugar or with palm sugar, Grated coconut, Pandan leaves, Water and Salt. And tools for making this cake are wooden spatula, bowl, saucepan, strainer, measuring jug, small cup for cake mould, and steamer for steaming the cake. The present form of the Sengkulun cake is known to be rectangular or parallelogram. Since there is no standard of the original form. Sengkulun cake there is a sell with a round shape and then put coconut shredded in a small plastic box one by one only in accordance with the order. This can be known from the results of interviews with business actors Sengkulun cake that is still there. The Table 9 show how is the presentation of Sengkulun cake at the moment.

Table 9. Presentation of Sengkulun Cake at the moment

\begin{tabular}{|c|c|}
\hline Informan & Answer \\
\hline 1 & $\begin{array}{l}\text { There is no possibility that our } \\
\text { friends as culinary experts, they } \\
\text { adjusts the taste of the people } \\
\text { now but the traditional touch with } \\
\text { the new packaging }\end{array}$ \\
\hline 2 & $\begin{array}{l}\text { If it changes shape is also not, it } \\
\text { is the system when the old time in } \\
\text { the form of a big slice. now there } \\
\text { is also what I see in already in the } \\
\text { form of small round shape in a } \\
\text { box }\end{array}$ \\
\hline 3 & Still in square shape \\
\hline 4 & We can use a lot of mould shape \\
\hline 5 & $\begin{array}{l}\text { Usually for engagement I use } \\
\text { love shape }\end{array}$ \\
\hline 6 & Still selling in square shape. \\
\hline 7 & Same size and shape until now \\
\hline 8 & $\begin{array}{l}\text { Usually for eid fitr I made it } \\
\text { small shape } n \text { put in small box } \\
\text { include coconut grated. }\end{array}$ \\
\hline
\end{tabular}


The results also show that Sengkulun cake need to be sustain because modern Betawi children today have not known this cake. The informant suggest the need to make this cake as a typical souvenir of Betawi, a new breakthrough in the packaging and cake form more interesting to be enjoyed by young people today. The Table 10 shows the way to preserve Sengkulun

Table 10. The Way to Preserve Sengkulun Cake

\begin{tabular}{cl}
\hline Informan & \multicolumn{1}{c}{ Answer } \\
\hline 1 & Keep this cake always exsist. \\
\hline 2 & $\begin{array}{l}\text { Not only need the role of } \\
\text { government in this case, I think the } \\
\text { community also play an active role } \\
\text { I think it is necessary there is also } \\
\text { a breakthrough that can be sold in } \\
\text { the form of the term day-to-day, } \\
\text { made a souvenir because it's been } \\
\text { so far not only dodol }\end{array}$ \\
\hline 3 & $\begin{array}{l}\text { By teachang and telling about } \\
\text { Sengkulun cake to young } \\
\text { generation }\end{array}$ \\
\hline 4 & $\begin{array}{l}\text { You as a young person must make } \\
\text { this cake still known }\end{array}$ \\
\hline 5 & $\begin{array}{l}\text { Keep making and sharing about } \\
\text { how to make this cake to young } \\
\text { generation }\end{array}$ \\
\hline 6 & $\begin{array}{l}\text { I still receive orders for sengkulun } \\
\text { until now }\end{array}$ \\
\hline 8 & Keep selling this cake until now \\
\hline Need to make this cake as snack \\
from betawi
\end{tabular}

\section{Method of Making Sengkulun Cake}

The results show that how to make Sengkulun cake is that it starts from cooking Javanese brown sugar with sugar and water until boiling and then let stand until cold. Then mix the glutinous rice flour with rice flour to mix well and then add the brown sugar solution to the glutinous rice flour mixture and then make the cake by hand or with the wood spatula, until it is in the form of small grains, then set aside in a separate bowl and combine with slice of palm sugar. Then the rest of the solution is mixed until it becomes one with a glutinous rice flour mixture until there is no clump. To avoid dough that clumps then the dough needs to be sieved. Then poured into the mold of Sengkulun cake then steamed until half-baked, freshly picked and then mixed with pulp grains with brown sugar to stick with the cake. The dough is steamed until cooked and ready to be served with grated coconut that has been steamed.

\section{Conclusion}

The Sangkulun cake has existed for a long time in the 14th century and it was preceded by the availability of glutinous rice that many people then Betawi people who get the influence of Malay and ethnic Chinese from seeing them make a basket cake then created this cake with the aim of the sengkulun people who are elder. This cake is formed Because often see ethnic Chinese in making basket cake but made easier in making this cake. Crackers in ancient times is used as a conductor for the elderly or considered penggede in the region which is given at the event and Eid al-Fitr. This cake has a philosophy that is strongly associated with sticky rice which is where the cake is in the application or even when the Eid can give the meaning that this sticky cake can make close relationship between husband and wife or glue the relationship between relatives in the family. This cake can already be enjoyed every day even its making techniques have started to extinct began to be reappointed by the author for this cake in the end can still be known by the Betawi people and also this cake can also be used as a special cake Betawi which can be made by souvenir typical Betawi The technique of making Sengkulun has been made and documented in the form of video and also photo and has been distributed to Betawi cultural institutions with the aim that this manufacturing technique to be preserved Betawi society.

\section{Suggestion}

Indonesian culture is so much we should be proud and appreciate our culture. It should be the younger generation can civilize and preserve indigenous culture of Indonesia and do not just imitate foreign culture. Generally, Indonesian people are more proud of foreign cultures that put forward a more luxurious and stylish culture but forget the original culture. Therefore, it is necessary to 
recognize the indigenous culture of Indonesia. Suggestion for Sengkulun that is expected to be done further research that lift Sengkulun with modification of more unique flavor again to Sengkulun can be Betawi snack which have many flavor choice.

\section{References}

Basuki and Sulistyo (2010) Metode Penelitian. Jakarta: Penaku.

Bogdan, R. and Taylor, S. J. (1992) 'Pengantar Metode Penelitian Kualitatif', Terjemahan Ali Furchon. Surabaya: Usaha Nasional.

Carl, E. H. (1985) What is History? England: Penguin Books Ltd.

Deny, S. (2014) Jakarta Makin Banyak Disambangi Wisatawan.

Dwi (2015) Perancangan Buku Kue Tradisional Khas Betawi. Bandung: Universitas Telkom.

Felicia, K. (2014) Pengaruh Budaya Betawi Pada Makanan Khas Imlek di Jakarta. Jakarta: Universitas Bina Nusantara.

Firta, H. (2015) Sate Lilit sebagai Kuliner Tradisional Bali. Jakarta: STP TRISAKTI.

Harold, H. T. (2015) Living issue in philosophy. New York: Oxford University.

Lila (2016) Evaluasi Bir Pletok sebagai welcome drink. Jakarta: STP TRISAKTI.

Martiah, S. (2013) Meningkatkan Minat Masyarakat Terhadap Produk Kuliner Tradisional. Jakarta: Universitas Indraprasta PGRI.

Murni, S. (2012) Kuliner Khas Betawi. Jakarta: Dinas Pariwisata dan KebudayaanProvinsi DKI Jakarta.

Sugiyono (2010) Metode penelitian Kuantitatif Kualitatif dan $R \& D$. Bandung: $C V$. Alfabeta.

http://ojs.unud.ac.id/index.php/eot

\section{Appendix}

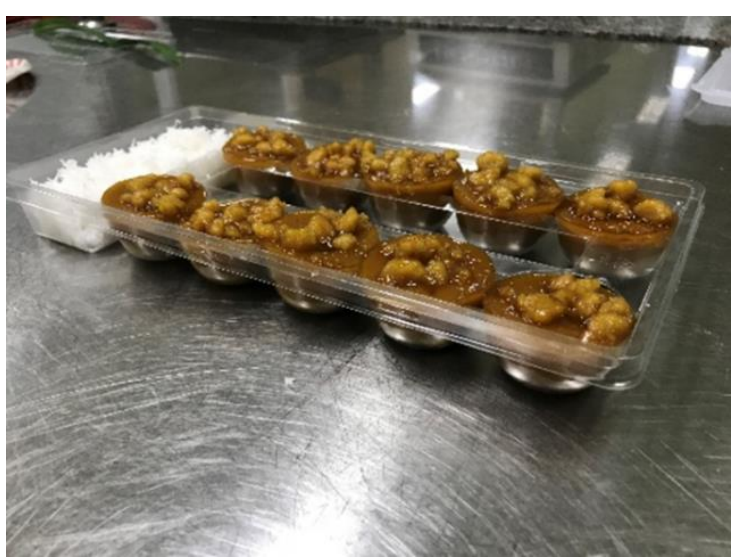

Picture Sengkulun already follow new style

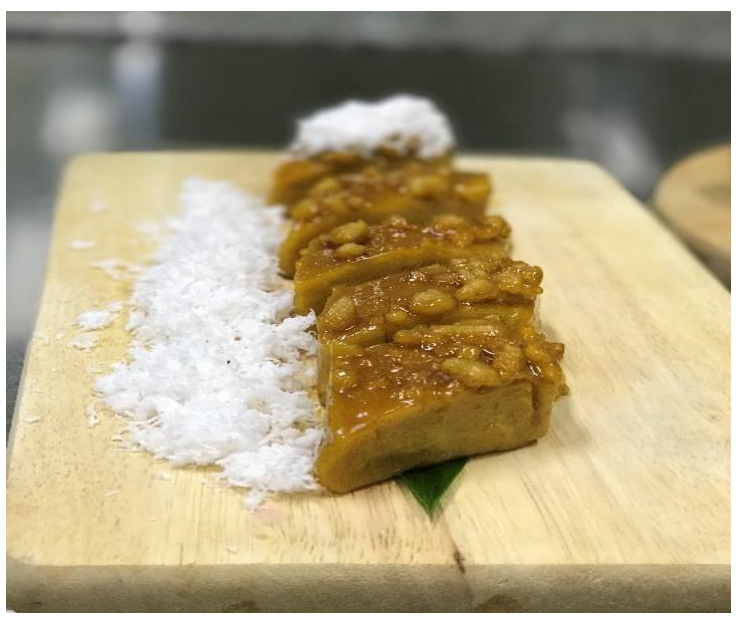

Picture Sengkulun in real shape.

Method of making Sengkulun :

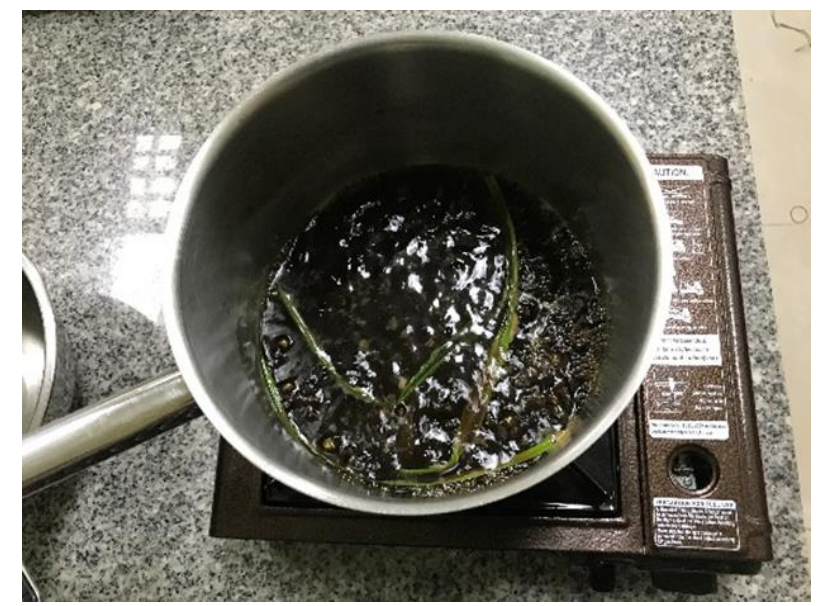

1. Boiled Palm sugar, pandan and water 


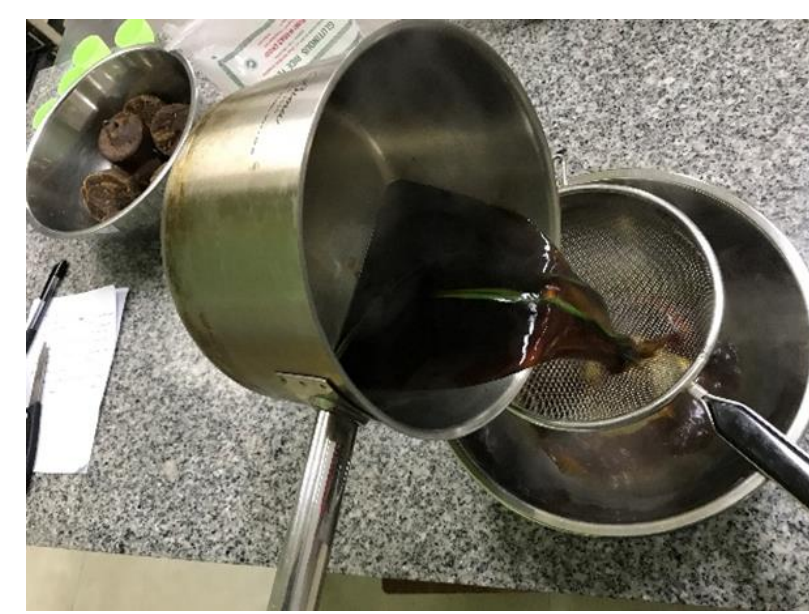

2. Strain palm sugar mixture

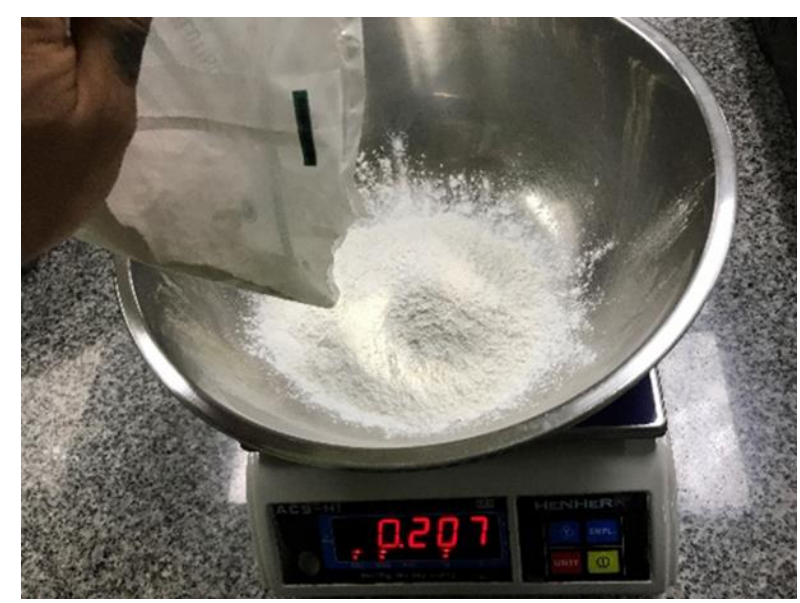

3. Scale glutinous rice flour and rice flour

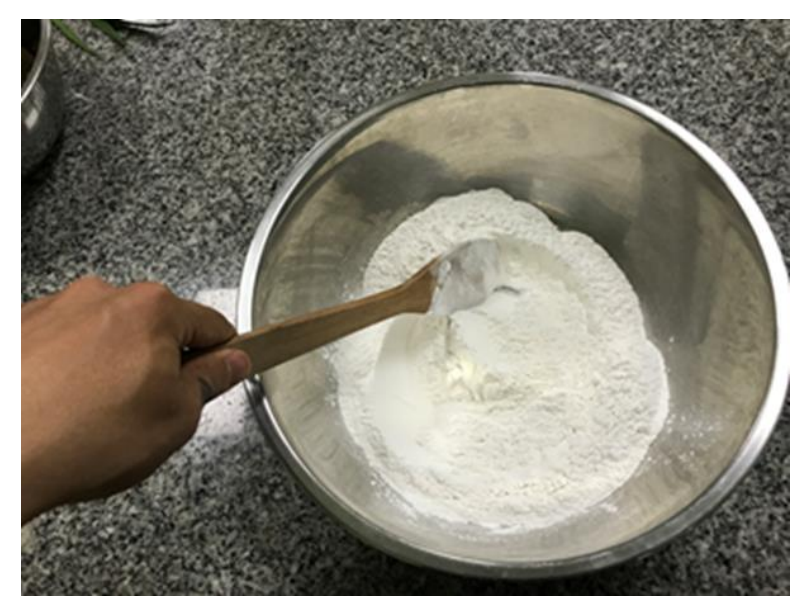

4. Mix the dry ingredient

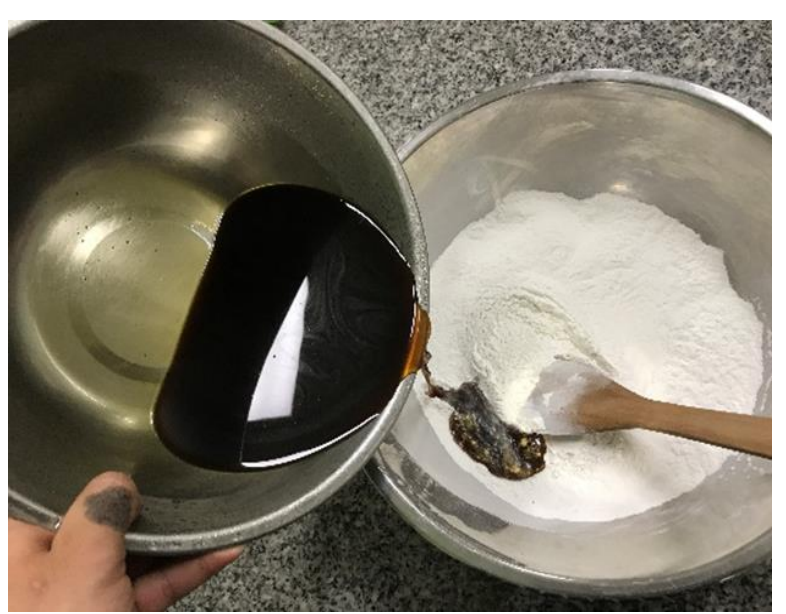

5. Mix the palm sugar mixture with dry ingredient

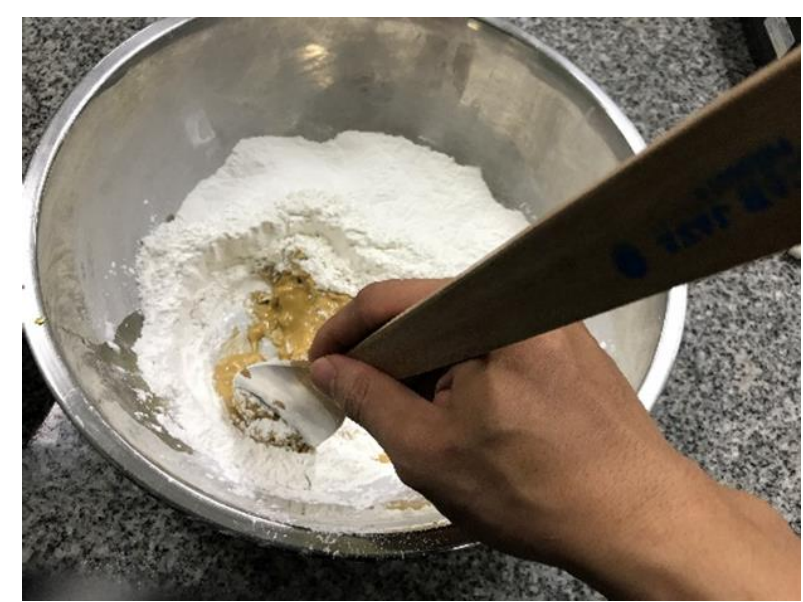

6. Make small pulun by spatula

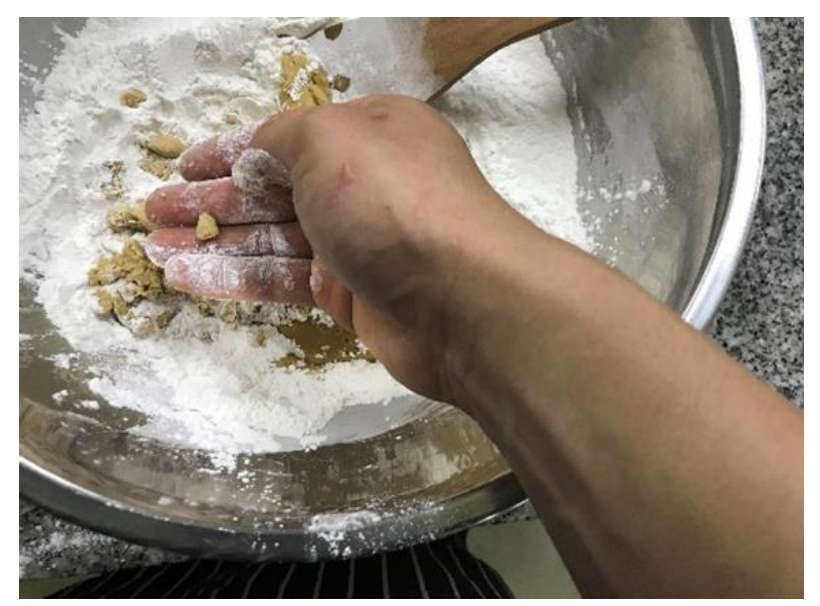

7. Making pulun by hand 


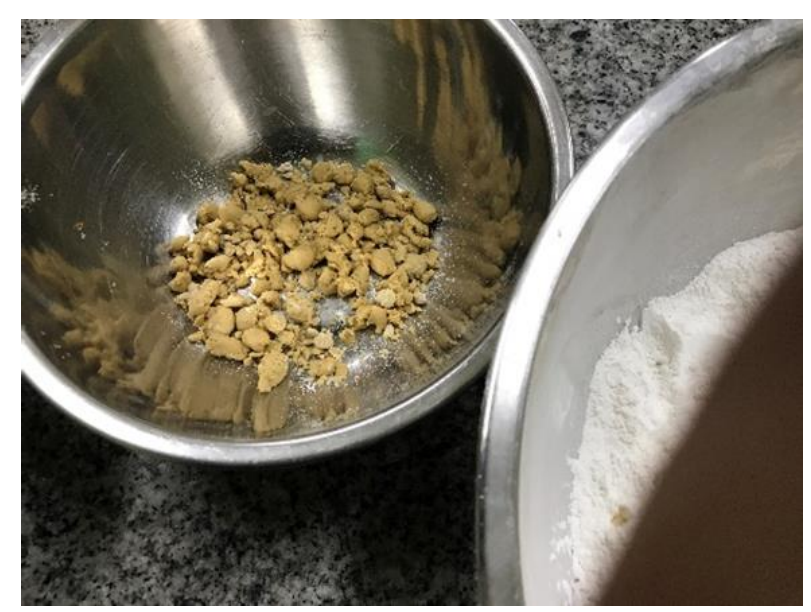

8. Seperated pulun in small bowl

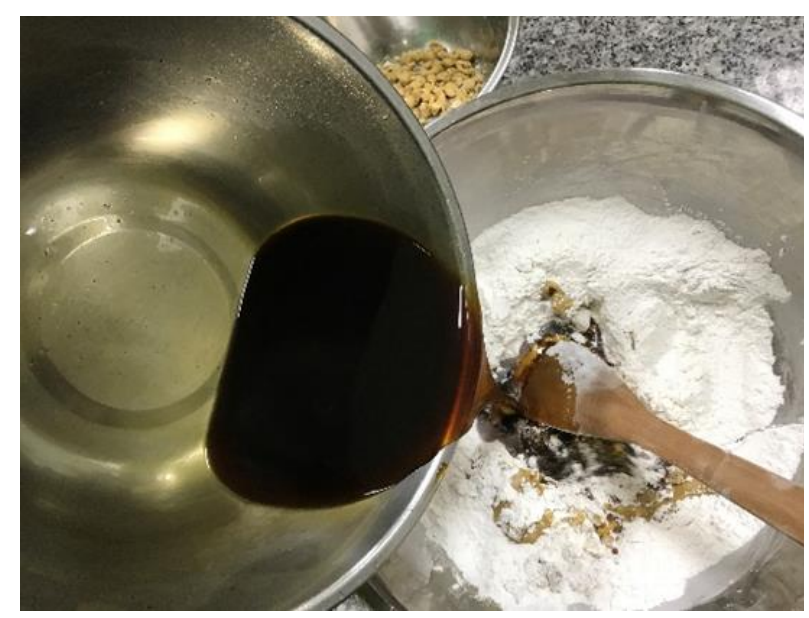

9. Mix the rest of palm sugar mix with dry ingredient

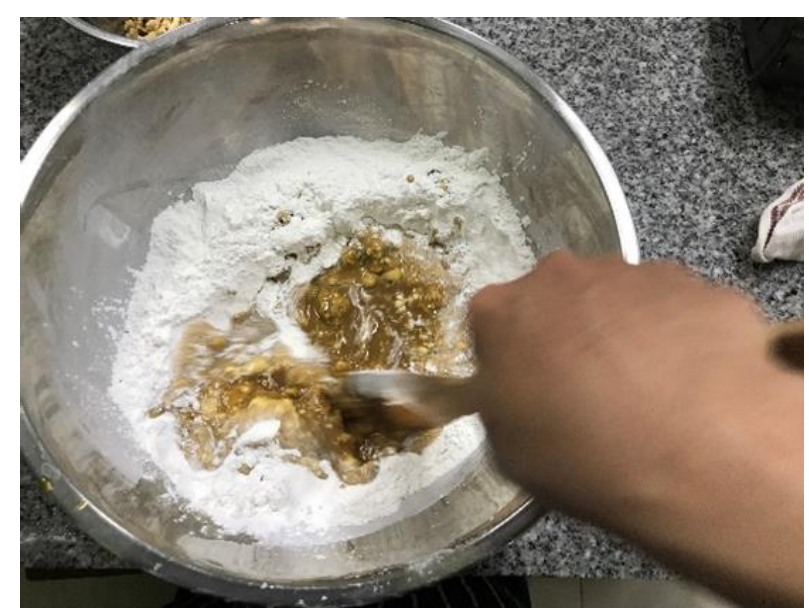

10. Mixwith spatula until well combine

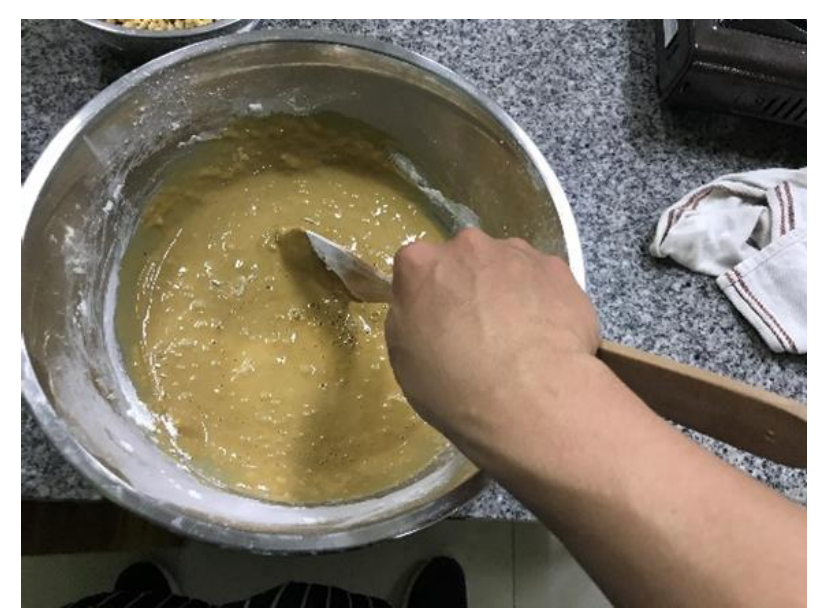

11. Mix all until no lumps

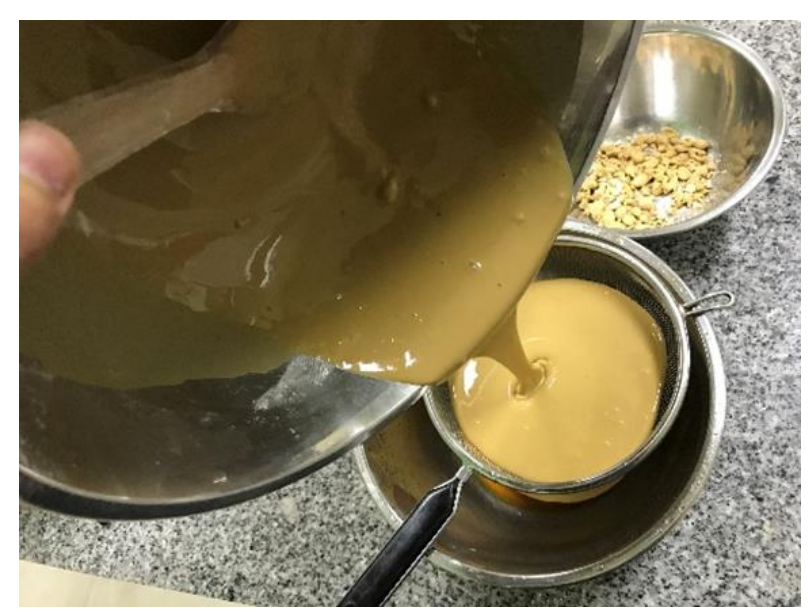

12. Strain the mixture until no lumps.

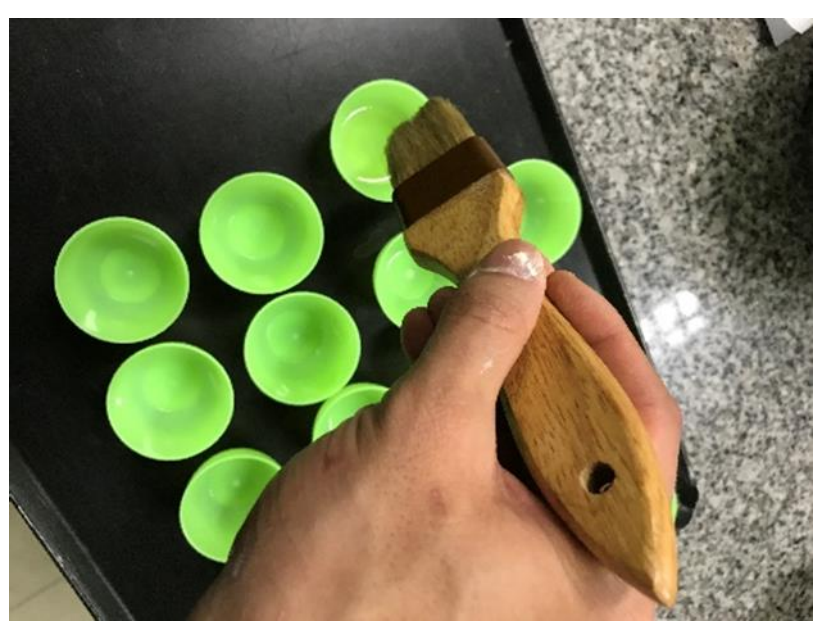

13. Prepare the mould, brush with oil 


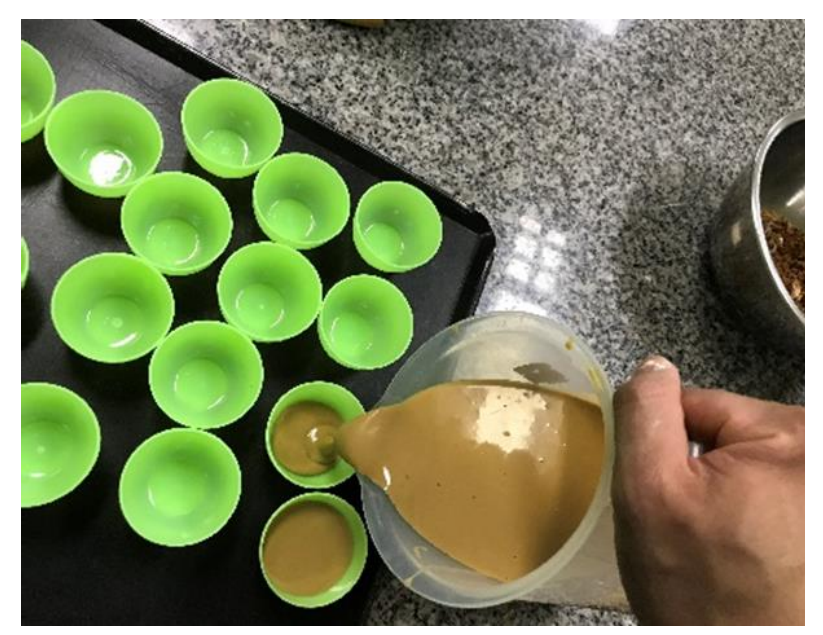

14. Pour the mixture to mould and steam for 5 minutes
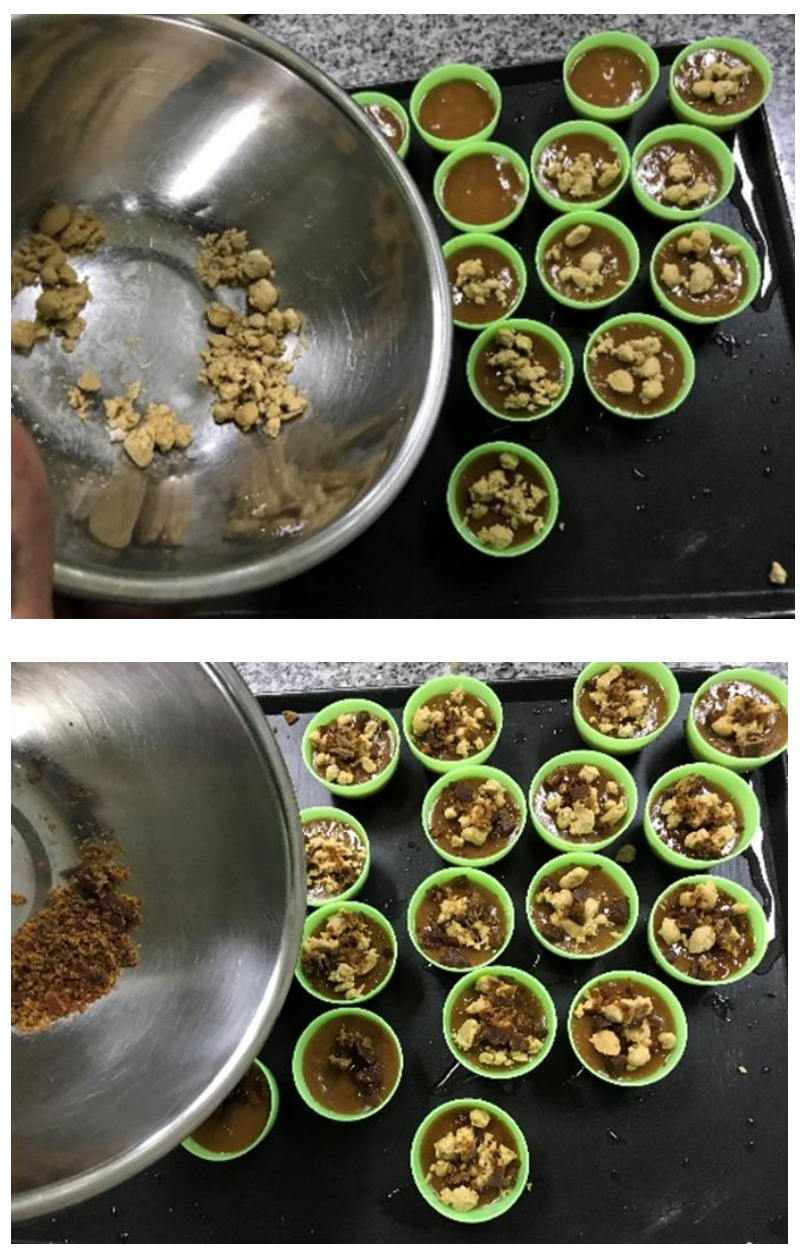

15. Add the pulun with shredded palm sugar and steam the cake until cook for 30 minutes.

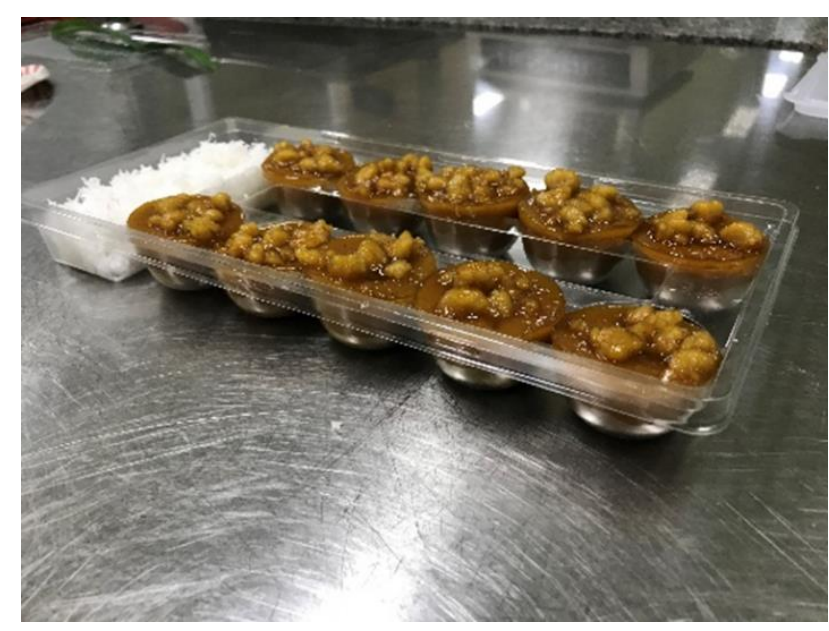

Let the Sengkulun cake getting cold and put in the packaging 